\title{
OKOLJEVARSTVENA PROBLEMATIKA ZASEBNIH ZELENJAVNIH VRTOV NA VODOVARSTVENIH OBMOČJIH LJUBLJANE
}

\author{
Sara Strajnar \\ Zavod RS za varstvo narave, Območna enota Kranj \\ Tomšičeva ulica 9, SI-4000 Kranj \\ e-mail: sara.strajnar@zrsvn.si
}

\section{Strokovni članek}

COBISS 1.04

\section{Izvleček}

Poleg vrtičkarskih območij se na vodovarstvenih območjih v Ljubljani in okolici, pojavljajo zasebni zelenjavni vrtovi. $Z$ vidika varstva okolja je tovrstno 'kmetijstvo v malem' oziroma ljubiteljsko vrtnarstvo zanimivo zaradi nenamernega obremenjevanja okolja. Prispevek povzema rezultate diplomskega dela, $\mathrm{v}$ katerem smo rezultate terenskega dela povezali $\mathrm{z}$ dostopnimi meritvami fitofarmacevtskih sredstev in rastlinskih hranil $\mathrm{v}$ tleh in pridelkih ter tako pridobili natančnejšo sliko o problematičnosti tovrstnega vrtnarstva.

Ključne besede: varstvo okolja, zasebni zelenjavni vrtovi, obremenjevanje okolja, ozaveščenost, vodovarstveno območje, Ljubljansko polje, Ljubljana.

\section{ENVIRONMENTAL PROTECTION: PRIVATE VEGETABLE GARDENS ON WATER PROTECTED AREAS IN LJUBLJANA}

\begin{abstract}
The areas of allotment gardens and private vegetable gardens are two types of 'small-scale agriculture' on water protected areas in Ljubljana and surroundings. From the environmental protection point of view, these gardens are important for the intensity of production and large number of gardeners. In author's graduation thesis the gardening habits have been investigated in detail. We combined data from field work with numerous measurements of phytopharmaceutical products and nutrients in soil and vegetables.
\end{abstract}

Key words: environmental protection, private vegetable gardens, burdening of environment, environmental awareness, water protection areas, Ljubljansko polje, Ljubljana. 


\section{UVOD}

V zadnjih letih je bilo na območju Ljubljane oziroma mestne občine Ljubljana veliko polemik o vrtičkarski dejavnosti, pri čemer se je poleg prostorske in pravne problematike omenjala tudi okoljevarstvena problematika teh površin. Na Geografskem inštitutu Antona Melika ZRC SAZU se je v letu 2008 zaključil triletni projekt Vrtičkarstvo v Mestni občini Ljubljana kot vir onesnaževal v tleh, podzemni vodi in pridelani hrani in prinesel podrobnejša spoznanja o okoljevarstvenih vidikih te dejavnosti. V Ljubljani in tudi na vodovarstvenih območjih Ljubljanskega polja pa se pojavlja podobna raba kot je vrtičkarska - zasebni zelenjavni vrtovi. Na problematiko zasebnih vrtov je v geografski stroki prvi opozoril Kladnik: »Najbrž vsaj toliko kot problematika vrtičkarstva je z vidika varovanja okolja pozornosti vredno tudi obdelovanje vrtov in vzdrževanje zelenic okrog individualnih hiš. Ker se vrtovi pojavljajo povsod v mestu, četudi so za ograjami manj vpadljivi in prikriti, kot celota zavzemajo sorazmerno velik obseg, ki ga je zaradi raznovrstnosti stanovanjskih sosesk z različnim gmotnim položajem in različnimi življenjskimi navadami stanovalcev, brez temeljitejših preučitev težko natančneje opredeliti.« (Kladnik 2003, 49). Poglavitni namen diplomskega dela Okoljevarstvena problematika zasebnih vrtov na vodovarstvenih območjih Ljubljane (Strajnar 2008), na podlagi katerega je nastal tudi pričujoči prispevek, je bil, bolje spoznati vrtnarske navade obdelovalcev ter jih ovrednotiti z vidika neželenih vplivov na okolje. Na eni strani gre za vplive na kvaliteto prsti in podtalnice, na drugi za vplive na zdravje ljudi (preko zaužite hrane).

Za območje raziskave smo izbrali ožja vodovarstvena območja Ljubljanskega polja (VVO I, VVO IIA, VVO IIB). Najprej je bila izdelana natančna evidenca zasebnih zelenjavnih vrtov, ki prikaže število vrtov, skupno površino vrtov in njihovo prostorsko razporeditev - njihov vzorec v prostoru.

Ker sta si pojava vrtičkov in zasebnih vrtov v marsičem podobna, smo v anketnem vprašalniku za obdelovalce zasebnih vrtov uporabili enaka vprašanja kot so bila predhodno zastavljena vrtičkarjem. Tako je bila omogočena medsebojna primerjava dobljenih rezultatov, zaradi skupno velikega vzorca pa se je vrednost rezultatov, ki se nanašajo na to 'kmetijstvo v malem', še povečala. Na drugi strani so bile za raziskavo zasebnih vrtov ključne meritve aktivnih ostankov fitofarmacevtskih sredstev ter rastlinskih hranil v prsti in pridelkih, saj le kemijske analize pokažejo objektivno stanje okoljskih sestavin. Te meritve je v okviru projekta Vrtičkarstvo v Mestni občini Ljubljana... (2007) izvedel Kmetijski inštitut Slovenije.

\section{METODOLOGIJA PREUČEVANJA OKOLJEVARSTVENE PROBLEMATIKE ZASEBNIH ZELENJAVNIH VRTOV}

Prednostni cilj izvedene raziskave je bil spoznati in ovrednotiti obdelovanje zasebnih zelenjavnih vrtov z vidika obremenjevanja okolja. $Z$ raznolikimi vprašanji, ki smo jih postavili 100 obdelovalcem vrtov, ugotavljamo značilnosti vrtnarjenja (obdelovalne navade) kot vira pritiskov na okolje ter v manjši meri okoljsko zavest. V okviru socialnogeografske metode smo raziskavo izvedli v štirih fazah:

- izdelava evidence zasebnih zelenjavnih vrtov na ožjih vodovarstvenih območjih Ljubljanskega polja (natančna ortofotointerpretacija barvnih posnetkov); 
- anketiranje 100 obdelovalcev zasebnih vrtov in analiza rezultatov (nenaključno vzorčenje, tako da smo razmeroma enakomerno pokrili celotno območje raziskave);

- pregled dostopnih rezultatov o stanju okoljskih sestavin (fitofarmacevtska sredstva, rastlinska hranila);

- vrednotenje problematike zasebnih zelenjavnih vrtov.

V začetni fazi je bila izdelana evidenca zasebnih zelenjavnih vrtov na ožjih vodovarstvenih območjih, pri čemer so bili zajeti vrtovi, večji od $5 \mathrm{~m}^{2}$. Skupna površina vrtov delno pokaže težo potencialno problematičnih območij, vendar le v določeni meri, saj dejstvo, da je z vrtnarjenjem povezanih mnogo ljudi, postavlja podatek o skupni površini vrtov z vidika varovanja okolja v precej drugačno (pomembnejšo in predvsem bolj zapleteno) luč.

Slika 1: Zelenjavni vrtovi so na natančnih ortofotoposnetkih dobro prepoznavni

Figure 1: On high-resolution orthophotographs, the vegetable gardens can be well discerned

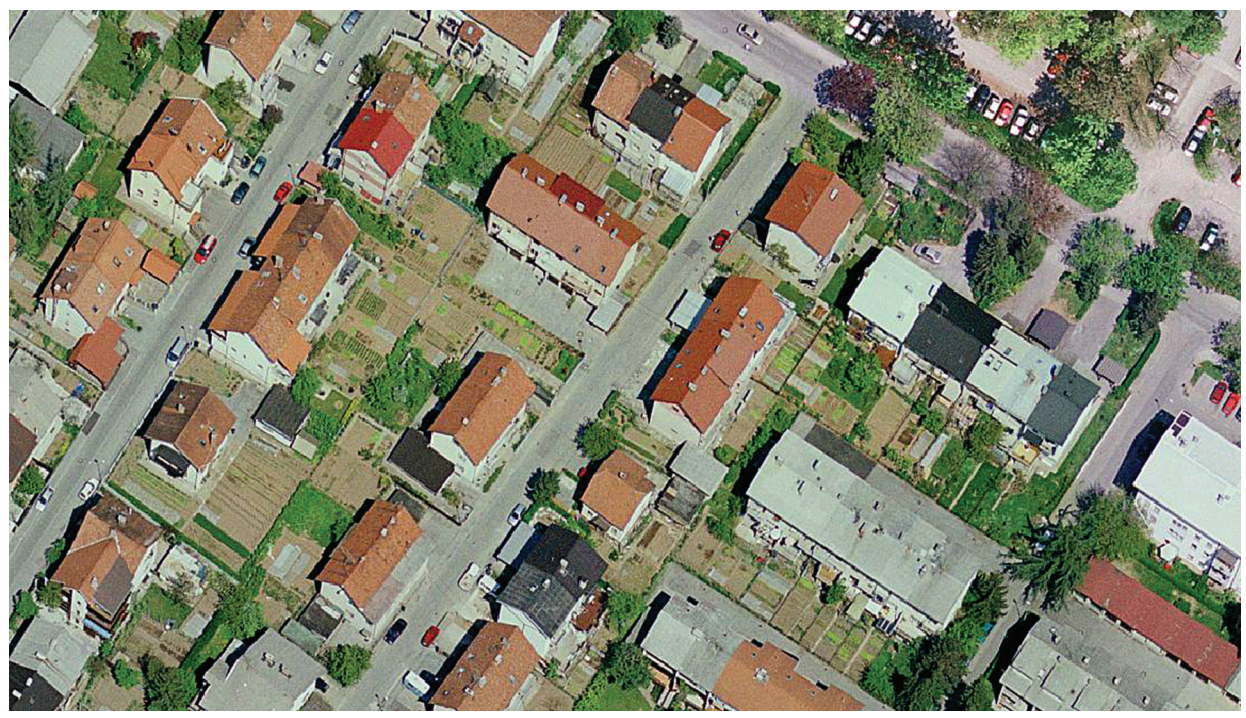

(Vir: Mestna občina Ljubljana 2005)

K veliki večini anketiranih obdelovalcev vrtov smo pristopili osebno ter s tem zmanjšali subjektivno razlaganje anketnih vprašanj. Hkrati pa tak pristop omogoča pridobitev dodatnih informacij, ki so pomembne, a po njih nismo spraševali. Anketna vprašanja so se nanašala na sam vrt (obseg, koliko let vrt obdeluje sedanji obdelovalec, pridelki na vrtu), na zavest o prostoru (ali vedo, da se vrtovi nahajajo na vodovarstvenih območjih), jedro ankete pa so sestavljala vprašanja o gnojenju in uporabi fitofarmacevtskih sredstev.

Anketiranje je potekalo med januarjem in marcem 2008 in naletelo na zelo dober odziv. To lahko delno razložimo z dejstvom, da so obdelovalci vrtov starejši ljudje, delno pa z izbiro časa za anketiranje (pozimi, ko so ljudje bolj doma). 


\section{RAZŠIRJENOST ZELENJAVNIH VRTOV V MESTNEM IN PRIMESTNEM PROSTORU}

$\mathrm{Na}$ ožjih vodovarstvenih območjih Ljubljanskega polja je bilo zabeleženih 5228 vrtov, vendar je zaradi nekoliko starejših digitalnih posnetkov (iz leta 2005 in v manjši meri iz leta 2003) in zaradi upadanja števila zasebnih vrtov danes ta številka manjša (Strajnar 2008). Digitalizirani zasebni vrtovi skupaj zavzemajo 27,6 ha površin na ožjih vodovarstvenih območjih, kar pomeni, da pokrivajo 0,36 \% površine vodovarstvenega območja IIA in $0,96 \%$ površine vodovarstvenega območja IIB (slika 2). Podatek o površini vrtov je bolj relevanten kot podatek o številu vrtov, saj je število vrtov odvisno od načina fotointerpretacije. V primeru vrstnih hiš, ko potka deli vrt na dva dela, smo zabeležili dva vrtova, lahko pa bi tudi enega. Vsekakor ne gre enačiti števila vrtov s številom obdelovalcev; je pa različnih obdelovalcev vrtov na ožjih vodovarstvenih območjih Ljubljanskega polja zagotovo nekaj tisoč.

Pri večkratnem in temeljitem terenskem ogledu je bilo zaznati razliko med dejanskim stanjem in številom vrtov na nekoliko starejših digitalnih posnetkih. Manj vrtov kot je pokazala digitalizacija smo zasledili v Dravljah, Šiški, za Bežigradom, v Brinju in Novih Jaršah. Vrtovi se krčijo in tudi izginjajo - v večini primerov jih nadomešča zelenica. Po pridobljenih podatkih lahko čez desetletje zaradi staranja sedanjih obdelovalcev pričakujemo

Slika 2: Zelenjavni vrtovi na ožjih vodovarstvenih območjih Ljubljanskega polja Figure 2: Vegetable gardens on inner water protected areas of Ljubljansko polje

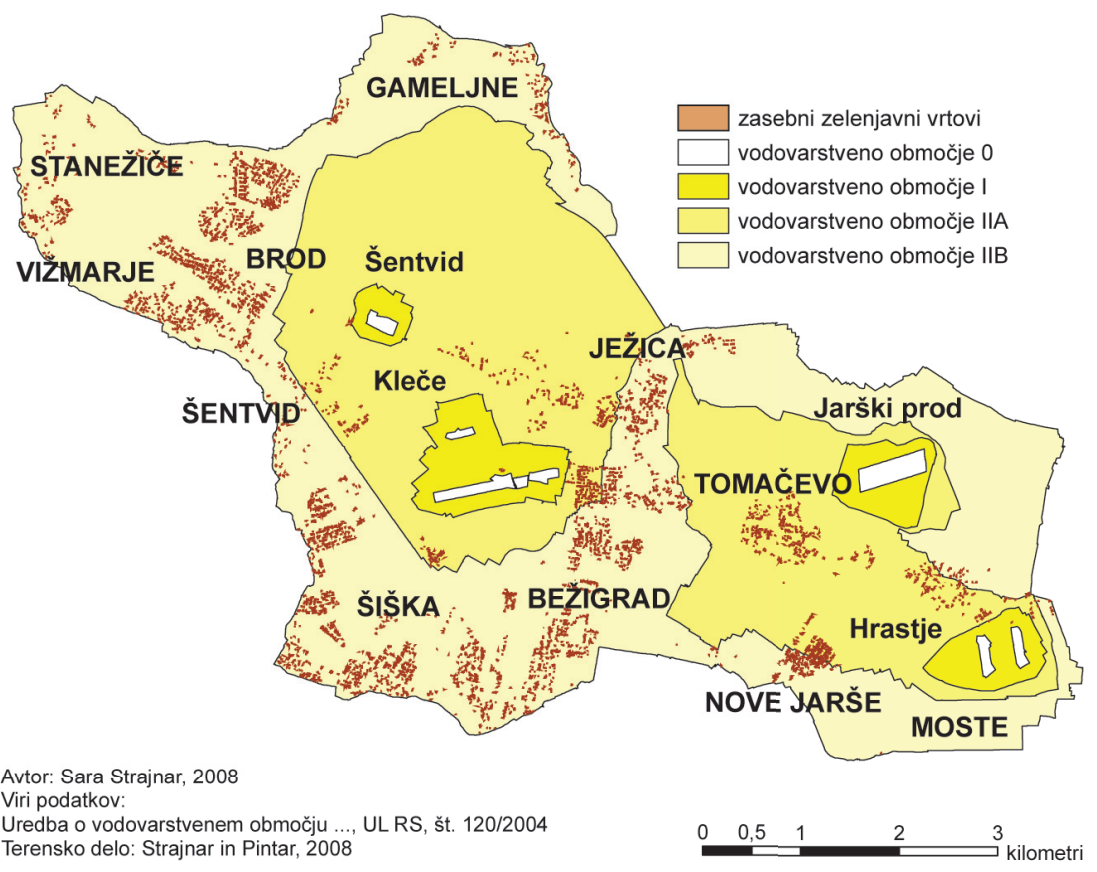


za 10-20 \% manj vrtov. Kljub trendu krčenja vrtov pa terenski pregled mestnih in primestnih območij Ljubljane pokaže, da se v urbani rabi najde še kar nekaj prostora za zelenjavne vrtove. Ponekod so prav slikovito stisnjeni med urbano rabo (slika 3).

Slika 3: Med urbano rabo se najde še dovolj prostora za vrtove (Ljubljana-Šiška) (foto: S. Strajnar 2007)

Figure 3: There is still enough space for gardens in urban area (Ljubljana-Šiška) (photo: S. Strajnar 2007)

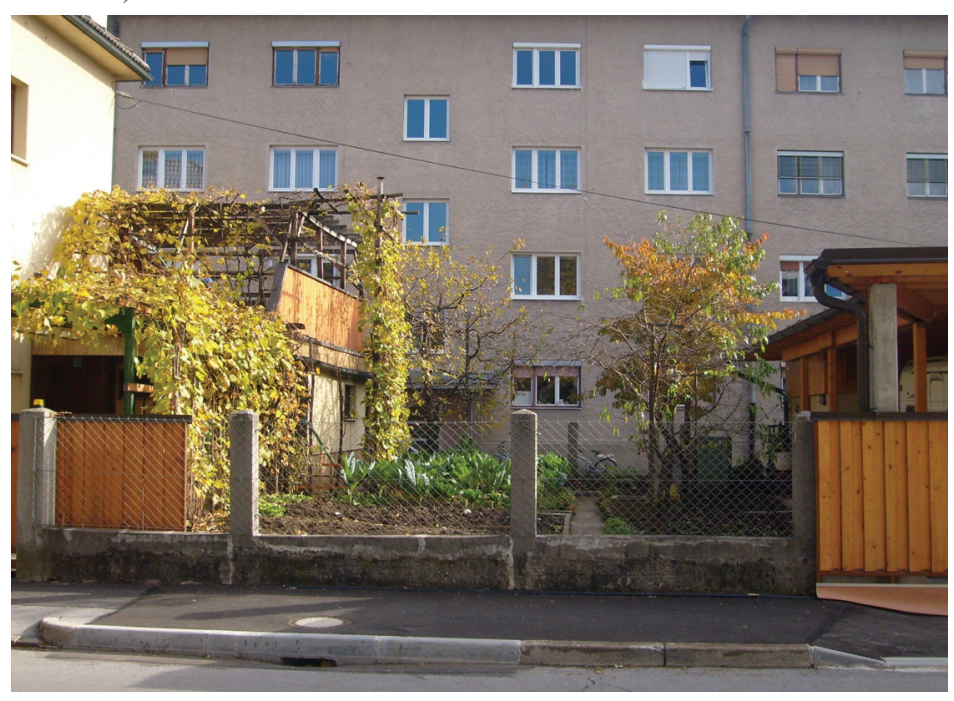

\section{OKOLJSKA ZAVEST OBDELOVALCEV VRTOV}

Uvodoma smo pri terenski raziskavi želeli izvedeti, kako dobro obdelovalci vrtov poznajo območje, kjer živijo oziroma obdelujejo vrt. Le 31 \% jih je pravilno vedelo, da je njihov vrt na vodovarstvenem območju, 52 \% jih je trdilo, da se njihov vrt ne nahaja na vodovarstvenem območju, 19 \% pa jih ni vedelo (slika 4). Na skromno poznavanje vodovarstvenih območij je opozoril že Smrekar (2006) in ugotovil, da so kmetovalci tista skupina ljudi, ki najbolje pozna ta območja. Glede na to, da je obdelovanje vrtov razmeroma trajna dejavnost in da večina anketirancev vrt obdeluje več kot 20 let, slabo poznavanje vodovarstvenih območij vsekakor ni spodbudno. Slabo poznavanje teh območij lahko deloma pojasnimo z dejstvom, da gre za starejše ljudi, ki niso bili deležni tako velike informiranosti o okoljskih temah in problemih kot mlajše generacije.

Najslabše poznavanje vodovarstvenih območij se je pokazalo v južnem in hkrati najbolj mestnem delu (Šiška, Bežigrad, Nove Jarše), zanimivo pa se je pokazalo slabo poznavanje vodovarstvenih območij tudi na Ježici - v pasu med dvema vodovarstvenima območjema kategorije IIA (slika 4). Pričakovano najbolje poznajo vodovarstvena območja obdelovalci vrtov v urbaniziranih vaseh na Ljubljanskem polju (Kleče, Savlje, Tomačevo, Šmartno, Hrastje). 
Slika 4: Poznavanje vodovarstvenih območij med obdelovalci zasebnih vrtov

Figure 4: Awareness of having gardens in water protected areas

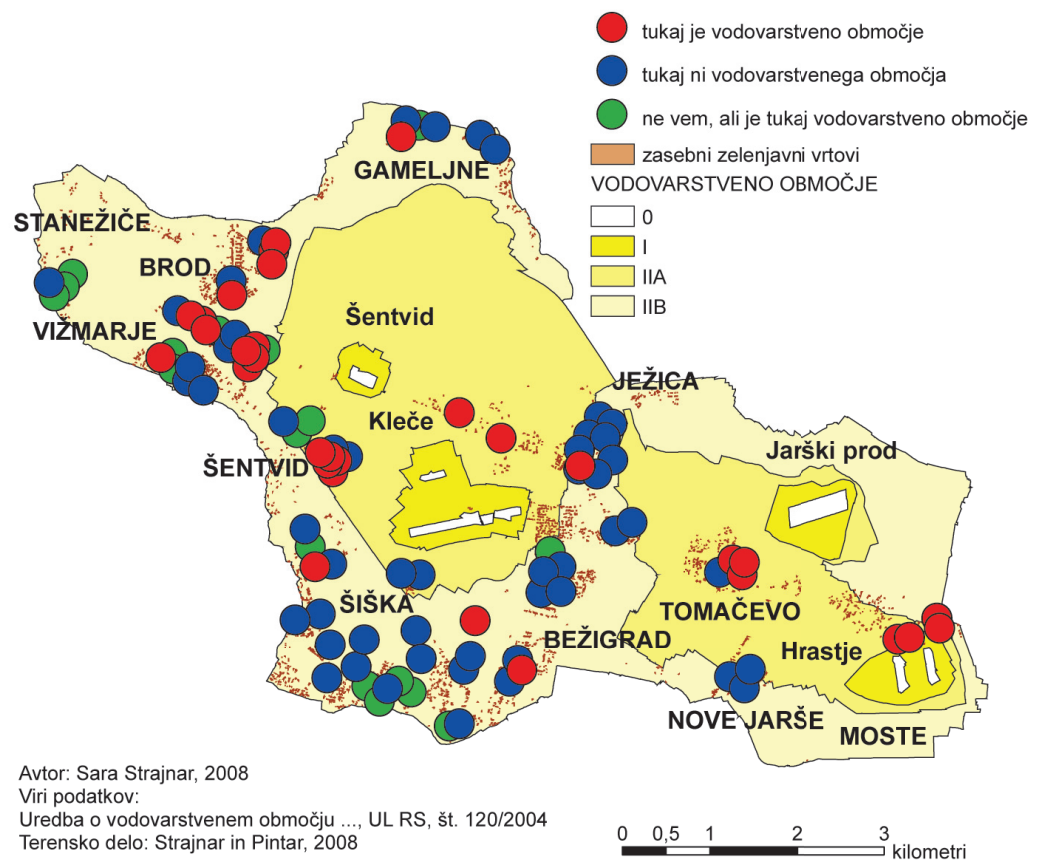

Poznavanje vodovarstvenih območij smo povezali z izobrazbeno sestavo. Povprečno izobrazbo anketiranih obdelovalcev smo primerjali s povprečno izobrazbo tistih obdelovalcev, ki pravilno vedo, da njihovi vrtovi ležijo na vodovarstvenem območju. Povprečna izobrazba vseh obdelovalcev znaša 2,66, tistih, ki vedo za vodovarstvena območja, pa 3,13 (z 1 smo ovrednotili osnovnošolsko izobrazbo, s 4 pa višje- ali visokošolsko izobrazbo). Obdelovalci vrtov, ki vedo, da njihovi vrtovi ležijo na vodovarstvenem območju, so torej bolje izobraženi od povprečja. Med obdelovalci vrtov, ki poznajo vodovarstvena območja, je veliko tistih z višjo ali visoko izobrazbo in jih (glede na njihovo starost in obdobje, ko so pridobili tako visoko izobrazbo), lahko štejemo za 'intelektualce'.

Na svojih vrtovih obdelovalci uporabljajo različne vrste gnojil in različna fitofarmacevtska sredstva. Zanimalo nas je, kako obdelovalci zasebnih zelenjavnih vrtov zaznavajo gnojila in fitofarmacevtska sredstva v povezavi z onesnaževanjem okolja. Kot okolju najmanj nevarna so izbrali organska gnojila, sledijo mineralna gnojila, pri fitofarmacevtskih sredstvih pa so v večini mnenja, da v vsakem primeru (če jih uporabimo) onesnažujemo okolje. Ker se zdijo organska gnojila daleč najmanj okoljsko škodljiva, so obdelovalci na potrebne odmerke gnoja manj pozorni. Pravilno bi bilo, da obdelovalci odmerke gnoja prilagodijo potrebam rastlin po hranilih. Zanimalo nas je, ali sploh ločijo različne potrebe po rastlinskih hranilih, ki jih imajo najbolj klasične vrtnine. Izbrali smo vprašanje o potrebnih hranilih pri paradižniku in solati. 
Paradižnik in solata sta dva ekstrema - paradižnik v splošnem potrebuje veliko rastlinskih hranil (gnojenja), solata pa malo (slika 5).

Slika 5: Katera vrtnina potrebuje več rastlinskih hranil - paradižnik ali solata?

Figure 5: Which vegetable needs more nutrients - tomato or salad?
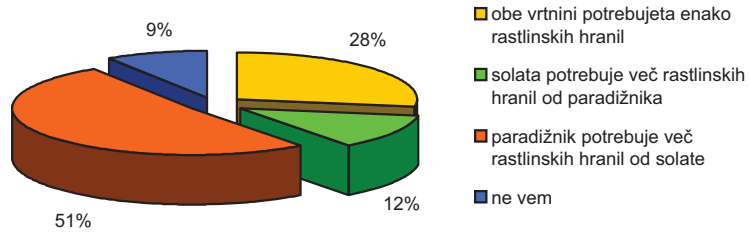

Vir: Terensko delo, Strajnar in Pintar, 2008, $N=100$

Kar polovica anketiranih obdelovalcev ne ve, da paradižnik potrebuje več rastlinskih hranil od solate. Na drugem mestu je odgovor, da obe vrtnini potrebujeta enako količino rastlinskih hranil, veliko manj jih meni, da solata potrebuje več rastlinskih hranil. Veliko anketirancev je, ne glede na to, ali so pravilno odgovorili na zgornje vprašanje, zatrdilo: »Gnojim pa vse enako.« Poznavanje potrebe po hranilih pri vrtičkarjih pri skoraj trikrat večjem vzorcu $(\mathrm{N}=284)$ pokaže podobno sliko: $53 \%$ anketiranih vrtičkarjev je izbralo pravilen odgovor, $22 \%$ jih je menilo, da rastlini potrebujeta enako rastlinskih hranil, $9 \%$ jih je menilo, da solata potrebuje več rastlinskih hranil, $16 \%$ odgovora ni vedelo (Anketiranje vrtičkarjev... 2006). Zbrani odgovori na vprašanje o paradižniku in solati nakazujejo, da so tako obdelovalci zasebnih vrtov kot obdelovalci vrtičkov v dobršni meri laično poučeni o poglavitnih rastlinah na vrtu in njihovih potrebah po gnojenju. Paradižnik in solata sta dva izmed najbolj klasičnih pridelkov na vrtovih, zato smo pričakovali boljše poznavanje omenjenih rastlin. Nepotrebno obremenjevanje prsti in pridelkov lahko torej izhaja iz pomanjkljivega znanja o rastlinah in njihovih značilnostih.

\section{GNOJENJE IN UPORABA FITOFARMACEVTSKIH SREDSTEV}

Pod tem poglavjem smo strnili odgovore na vprašanja, ki so sestavljala jedro raziskave.

Skoraj vsi obdelovalci vrtov, ki smo jih zajeli, gnojijo. Glavno vlogo pri izbiri in uporabi gnojil odigrajo lastne izkušnje, v kar $65 \%$. Na drugem mestu sledijo nasveti prodajalcev. Lastne izkušnje oziroma »zdrava kmečka pamet«, kot pravi marsikateri anketirani obdelovalec, lahko z vidika uporabe gnojil (predvsem količine gnojil) poleg vseh pozitivnih stvari pomenijo določeno mero nestrokovnosti. Izkušnje oziroma navade pripomorejo k temu, da se obdelovalci o stvareh, povezanih z gnojenjem, manj sprašujejo oziroma se manj posvetujejo s strokovnjaki. Anketiranje je pokazalo, da so gnojilne navade zelo raznolike, obdelovalci pa ponavadi kombinirajo več vrst gnojil. Gnojenje z živinskimi gnojili (hlevski gnoj) upada; glavni razlog za to so težave $\mathrm{z}$ dobavo živinskega gnoja (upad števila kmetov v okolici Ljubljane). Hlevski gnoj so zamenjali briketi živinskega gnoja (organsko gnojilo) in 
mineralna gnojila. Povečuje se tudi uporaba bioloških gnojil. Splošni vtis je, da obdelovalci vrtov kar precej gnojijo. V primerjavi s pazljivostjo, ki jo pri obdelovalcih vrtov opazimo pri uporabi fitofarmacevtskih sredstev, pravilnemu gnojenju namenjajo veliko manj pozornosti.

Primerjava podatkov dveh terenskih raziskav (Vrtičkarstvo v MOL 2007; raziskava med zasebnimi zelenjavnimi vrtovi, 2008) nam pokaže, da so mineralna gnojila pri vrtičkarjih manj zastopana kot pri obdelovalcih zasebnih zelenjavnih vrtov (slika 6). Če podatkom verjamemo, lahko sklepamo, da so vrtičkarji glede uporabe vrst gnojil bolj ekološki kot obdelovalci zasebnih vrtov. Zasebni vrtovi ležijo tik ob hišah, velika skrb za zelenjavne vrtove pa se lahko odraža v večjem obremenjevanju okolja (prsti) v primerjavi z vrtički, ki so ločeni od kraja bivanja in niso kadarkoli dostopni. Vrečke mineralnih gnojil se v individualnih hišah (v kleteh) tudi lažje spravijo kot na vrtičkarskih območjih.

Slika 6: Uporaba gnojil med obdelovalci zasebnih vrtov

Figure 6: Use of fertilizers on private vegetable gardens

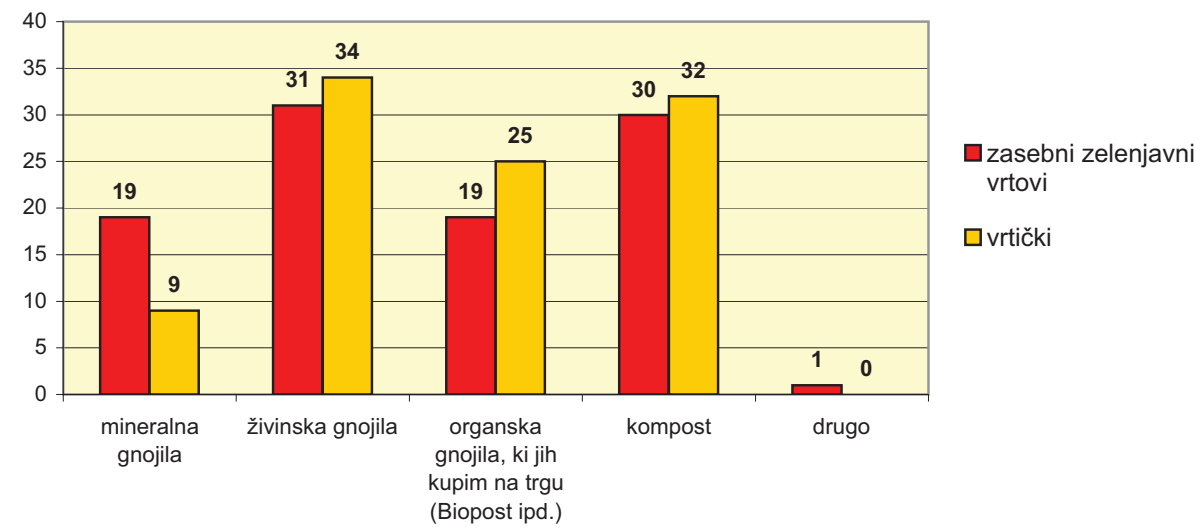

Vrtne prsti so zaradi gnojenja običajno zelo rodovitne; to pomeni, da vsebujejo veliko rastlinskih hranil. Kmetijski inštitut Slovenije opravlja analize prsti za naročnike, med katerimi so tudi lastniki zelenjavnih vrtov, vendar analiz v svoji evidenci nimajo ločenih po namenski rabi površine, od koder so bili vzorci vzeti (na primer s travnika, z njive, zasebnega vrta). Zato nismo mogli izračunati povprečja rezultatov večjega števila analiz prsti z zasebnih zelenjavnih vrtov, obstaja pa splošen podatek, da je večina vrtov in vrtičkov preveč gnojenih (Sušin 2008, osebni vir). Dve obsežni raziskavi, ki sta bili opravljeni v letih 1997-99 (analize vrtov, vključno z deli njiv, kjer gojijo zelenjavo; $N=220)$ in v letu 2006 (100 analiz vzorcev prsti z ljubljanskih vrtičkov) sta pokazali, da je več kot tri četrtine vzorcev prsti ekstremno založenih s fosforjem, nekoliko manjšo prekomerno založenost pa beležimo pri kaliju. Vzroke za takšno stanje najdemo v preobilnem gnojenju in neupoštevanju dejanskih potreb po hranilih za posamezne vrste rastlin. 
Iz rezultatov vsebnosti nitratov v pridelani zelenjavi (endiviji in radiču,) na vrtičkarskih območjih v Ljubljani (Vrtičkarstvo v Mestni občini Ljubljana.... 2007) je razvidno, da vrtnine vsebujejo preveč nitratov. Nitrati sami po sebi niso tako toksični, veliko bolj so nitriti, ki nastanejo pri razkroju nitratov v človeškem organizmu. Vsebnost nitratov v pridelkih je poleg gnojenja pogojena tudi z vrsto pridelka. Tako največ nitratov kopiči zelena listnata zelenjava (solatnice, špinača, zelje ipd.), mnogo manj pa nekatere druge vrste zelenjave. Zato sta bila v okviru omenjenega projekta na vsebnost nitratov analizirana endivija in radič (N =97). V $22 \%$ vzorcev je koncentracija nitratov znašala nad $1000 \mathrm{mg} / \mathrm{kg}$, $\mathrm{kar}$ je bilo z vidika onesnaženosti zelenjadnic ovrednoteno z 'neprimerno', skupaj z razredom 'manj primerno' pa se je odstotek povečal na skoraj polovico odvzetih vzorcev (Polajnar 2008).

Poleg gnojil so pri obdelovanju vrtov pomembni še vnosi fitofarmacevtskih sredstev. Glede na to, da so obdelovalci vrtov kot glavni motiv izbrali pridelovanje zdrave hrane, večjih (pogostejših) vnosov fitofarmacevtskih sredstev ne pričakujemo. Ker pa gre za agresivne in strupene snovi, je pazljivost pri pravilni uporabi fitofarmacevtskih sredstev toliko bolj pomembna.

Več kot polovica oziroma $57 \%$ anketiranih obdelovalcev zasebnih vrtov je trdila, da fitofarmacevtskih sredstev pri obdelovanju zelenjavnega vrta nikoli ne uporablja. Veliko več obdelovalcev je fitofarmacevtska sredstva uporabljalo pri vzgoji vrtnic in sadnega drevja, toda pričujoča raziskava omenjenega področja ne pokriva. $43 \%$ anketiranih obdelovalcev zasebnih vrtov je uporabljalo fitofarmacevtska sredstva, najpogosteje ob pojavu bolezni ali škodljivca (69 \%), manj pozimi oziroma v prvi polovici rastne dobe $(19 \%)$, v rednih časovnih presledkih v rastni dobi pa je fitofarmacevtska sredstva uporabljalo $5 \%$ obdelovalcev. $7 \%$ obdelovalcev, ki so uporabljali fitofarmacevtska sredstva, je navedlo, da tovrstna kemična sredstva uporabljajo le redko (ne vsako leto). Okoljsko bi bili lahko še najbolj sporni tisti, ki rastline s fitofarmacevtskimi sredstvi tretirajo $\mathrm{v}$ rednih časovnih presledkih $\mathrm{v}$ rastni dobi, ker gre pri tem vzorcu uporabe verjetno za nekoliko večje vnose. Raziskava je tako pokazala, da razmeroma veliko (dobrih $40 \%$ ) obdelovalcev fitofarmacevtska sredstva kupuje in uporablja, toda veliko kupljenih sredstev je bioloških (Kalia 2008; Vrtko 2008), pa tudi dejanska uporaba je redka.

Pri vrtičkarjih je opaziti razliko med deklarativnim in dejanskim ravnanjem (Rejec Brancelj, Smrekar in Kladnik 2005). To dejstvo nas lahko zavede pri raziskovanju in sklepih o biološkem vrtnarjenju. Obdelovalce vrtov smo povprašali, kako ocenjujejo lasten način vrtnarjenja in odgovore povezali z vprašanjem o uporabi fitofarmacevtskih sredstev. Ugotovili smo, da se na deklarativni ravni obdelovalci hitreje izrečejo za ekološko obdelovanje kot to dejansko in strogo izvajajo. Pokazalo se je, da je dobra tretjina obdelovalcev, ki je trdila, da vrtnari ekološko, hkrati uporabljala fitofarmacevtska sredstva (slika 7). Sicer pa je največ (53\%) anketiranih obdelovalcev menilo, da vrtnarijo klasično, $43 \%$, da vrtnarijo ekološko, $3 \%$ anketiranih obdelovalcev pa so navedli svoj način vrtnarjenja.

Do omenjene dvojnosti med deklarativnim in dejanskim ravnanjem prihaja verjetno zaradi dejstva, da so obdelovalci vrtov zelo majhni in le občasni uporabniki fitofarmacevtskih sredstev. Zato dokaj hitro trdijo, da vrtnarijo ekološko. Vpliv uporabe fitofarmacevtskih sredstev na kakovost pridelkov so pokazale analize vsebnosti ostankov fitofarmacevtskih sredstev v 96 odvzetih vzorcih radiča in endivije na vrtičkih (Polajnar 2008), ki so bile izvedene 
v okviru projekta Vrtičkarstvo v Mestni občini Ljubljana.... (2007). Ker podobnih analiz z zasebnih zelenjavnih vrtov nimamo, so to za našo raziskavo najbolj relevantni podatki. Vzorci zelenjadnic so bili testirani na širok nabor ostankov fitofarmacevtskih sredstev. Vsebnost ostankov fitofarmacevtskih sredstev niti pri enem vzorcu ni presegla detekcijske meje metode. Iz teh podatkov lahko torej sklepamo na neoporečnost hrane z vrtov z vidika uporabe fitofarmacevtskih sredstev. Za še natančnejše vrednotenje in ugotovitev obstoječega stanja kakovosti pridelkov bi bile potrebne analize pridelkov, pri katerih obdelovalci navajajo, da uporabljajo največ sredstev. To so na zasebnih vrtovih v prvi vrsti paradižnik, sledijo fižol, krompir in paprika. Tudi rezultati analiz stotih vzorcev prsti, odvzetih z vrtičkarskih območij v Ljubljani, pokažejo, da vsebnost fitofarmacevtskih sredstev v veliki večini ne presega detekcijske meje uporabljene metode. Le v enem vzorcu so ugotovili sledove atrazina (Kmetijski inštitut Slovenije 2006).

Slika 7: Način vrtnarjenja in uporaba fitofarmacevtskih sredstev med obdelovalci zasebnih vrtov

Figure 7: Ways of gardening and use of phytopharmaceutical products among the gardeners

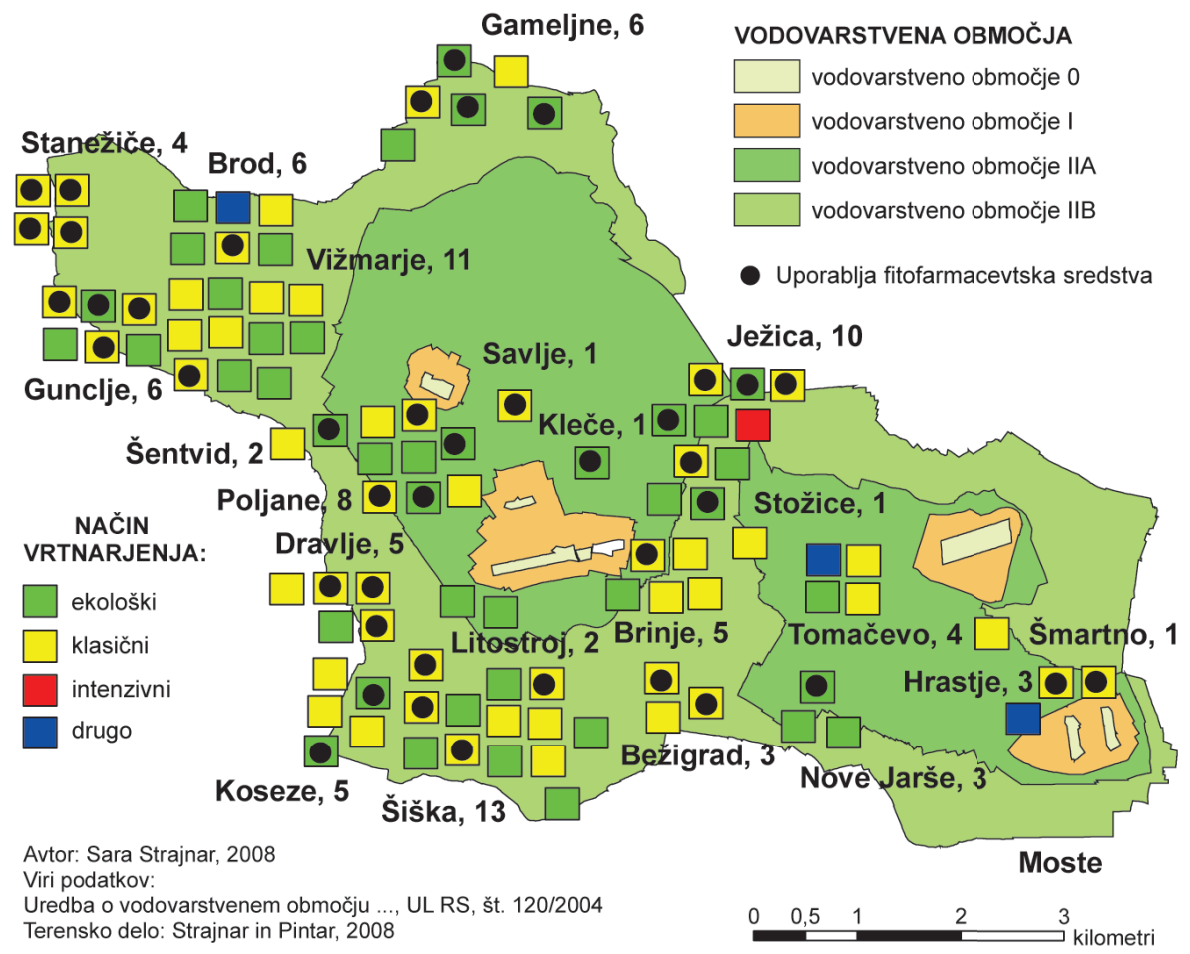


Rezultati anketiranja med obdelovalci zasebnih vrtov podpirajo navedene meritve. Uporaba fitofarmacevtskih sredstev se po podatkih anketiranja zmanjšuje; skoraj polovica obdelovalcev, ki fitofarmacevtska sredstva uporablja, je trdila, da porabi manj sredstev kot pred desetletjem. Vsekakor obdelovalci vrtov vedno bolj kupujejo biološke pripravke, pripravljajo pa jih tudi sami (namakajo koprivo, preslico in podobno). Tudi v prodajalnah je na izbiro vedno več bioloških sredstev za zatiranje škodljivcev (Kalia 2008; Vrtko 2008, osebna vira). Leta 2007 je zakon o uporabi in prodaji fitofarmacevtskih sredstev močno omejil prodajo fitofarmacevtskih sredstev, za nakup pa je potrebno pokazati izkaznico, s katero kupec dokaže, da ima opravljen tečaj iz uporabe sredstev za varstvo rastlin. Med terenskim delom smo naleteli na 5 obdelovalcev vrtov, ki so imeli ta tečaj že opravljen ali pa se ga bodo udeležili v bližnji prihodnosti. Ti obdelovalci predstavljajo skupino, ki se uporabi fitofarmacevtskih sredstev ne odreka in jo področje uporabe sredstev v povezavi z vrtnarjenjem nekoliko bolj poglobljeno zanima.

\section{SKLEP}

Obdelovanje zasebnih zelenjavnih vrtov je ljubiteljsko vrtnarstvo, ki je še relativno dobro zastopano $\mathrm{v}$ mestnem in primestnem prostoru Ljubljane. Zasebne zelenjavne vrtove najdemo $\mathrm{v}$ vseh soseskah individualnih in vrstnih hiš, seveda z različno gostoto. Vrtovi imajo velik pomen v življenju starejših ljudi, saj vrtnarjenje zadovoljuje vrsto različnih potreb posameznika. Ker tovrstna aktivnost omogoča neposreden stik $\mathrm{z}$ naravo in možnost aktivnega sodelovanja $\mathrm{v}$ spreminjanju okolja, pomembno vpliva na kvaliteto življenja meščanov.

V zadnjem času se je na področju varstva okolja opozarjalo na problematiko malih obdelovalcev (predvsem vrtičkarjev), ki bi lahko zaradi laičnega pristopa $\mathrm{k}$ vrtnarjenju nenamerno obremenjevali okolje in svoje zdravje. Vzporedno z zaključno fazo projekta Vrtičkarstvo $v$ Mestni občini Ljubljana kot vir onesnaževal v tleh, pridelani hrani in podzemni vodi (2007) je bila izpeljana raziskava o zasebnih zelenjavnih vrtovih. Za prostorski okvir smo izbrali ožja vodovarstvena območja Ljubljanskega polja, ki so še posebej občutljiva za vsakršno onesnaževanje. Podatki terenskega dela (anketirali smo 100 obdelovalcev vrtov) so nam v kombinaciji s podatki daljših anket Geografskega inštituta Antona Melika ZRC SAZU za vrtičkarje (imeli smo enaka vprašanja) ter $\mathrm{z}$ upoštevanjem podatkov številnih analiz, ki jih je $\mathrm{v}$ okviru omenjenega projekta opravil Kmetijski inštitut Slovenije, dovolj dobro pokazali okoljevarstveno problematiko tovrstnega ljubiteljskega vrtnarjenja.

Natančna fotointerpretacija sicer nekoliko starejših letalskih posnetkov (iz leta 2005 in v manjši meri iz leta 2003) je pokazala, da številni zasebni zelenjavni vrtovi na ožjih vodovarstvenih območjih zasedajo okoli27,6hektarjev površin in pokrivajo $0,36 \%$ vodovarstvenega območja IIA in $0,95 \%$ vodovarstvenega območja IIB. Med dvomesečnim terenskim delom (2008) na Ljubljanskem polju smo na nekaterih območjih zasledili (občutno) manj vrtov, kot jih je predhodno pokazala analiza posnetkov. Zelenjavni vrtovi ob hišah se krčijo in tudi izginjajo. Čez desetletje lahko pričakujemo 10-20 \% vrtov manj, predvsem zaradi staranja sedanjih obdelovalcev in hkratne nezainteresiranosti mladih za obdelovanje vrta.

Tako kot velja za druge skupine ljudi na vodovarstvenih območjih (Smrekar 2006), je tudi med obdelovalci vrtov poznavanje (ožjih) vodovarstvenih območij razmeroma skromno. Le 
slaba tretjina anketiranih obdelovalcev je vedela, da se njihov vrt nahaja na vodovarstvenem območju. Zgornji podatek je še zlasti zanimiv, ker je le $7 \%$ anketirancev obdelovalo zelenjavni vrt manj kot 20 let. Kljub temu da obdelovalci na vodovarstvenih območjih vrtnarijo že zelo dolgo, poznavanje za oskrbo z vodo pomembnih območij ostaja skromno.

Preglednica 1: Poglavitne ugotovitve raziskave med obdelovalci vrtov

Table 1: Main results from research among gardeners on private gardens

\begin{tabular}{|c|c|c|c|c|c|}
\hline \multicolumn{6}{|c|}{ ANKETIRANJE OBDELOVALCEV VRTOV } \\
\hline $\begin{array}{l}\text { Poznavanje prostora - } \\
\text { vodovarstvenih območij }\end{array}$ & Da: $31 \%$ & \multicolumn{3}{|c|}{ Ne: $52 \%$} & $\begin{array}{c}\text { Ne vem: } \\
17 \%\end{array}$ \\
\hline \multicolumn{6}{|l|}{ GNOJENJE } \\
\hline Čas gnojenja & $\begin{array}{l}\text { Jeseni, po spra- } \\
\text { vilu pridelkov: } \\
\quad 66 \%\end{array}$ & \multicolumn{3}{|c|}{ Spomladi, pred setvijo/ saditvijo: $24 \%$} & $\begin{array}{l}\mathrm{V} \text { času rasti: } \\
10 \%\end{array}$ \\
\hline $\begin{array}{l}\text { Vrste gnojil } \\
(* \text { razmerje med } \\
\text { posameznimi vrstami) }\end{array}$ & $\begin{array}{l}\text { Živinska gnojila: } \\
31 \%\end{array}$ & $\begin{array}{l}\text { Kompost: } \\
31 \%\end{array}$ & \multicolumn{2}{|c|}{$\begin{array}{c}\text { Umetna organska gnojila } \\
\text { (Biopost, Biograna, } \\
\text { Organik idr.): } 19 \%\end{array}$} & $\begin{array}{l}\text { Mineralna } \\
\text { gnojila: } \\
19 \%\end{array}$ \\
\hline $\begin{array}{l}\text { Oddaja vzorca prsti v } \\
\text { analizo (kadarkoli) }\end{array}$ & \multicolumn{2}{|l|}{$\begin{array}{l}\text { Da: } 11 \% * * \\
\text { (Vrtičkarji: Da: } 2 \%)\end{array}$} & \multicolumn{3}{|c|}{ Ne: 89 \% } \\
\hline \multicolumn{6}{|c|}{ UPORABA FITOFARMACEVTSKIH SREDSTEV } \\
\hline Uporaba sredstev & Da: $43 \%$ & \multicolumn{2}{|c|}{ Ne: $57 \%$} & & \\
\hline $\begin{array}{l}\text { Čas uporabe (odgovarjali } \\
\text { so samo obdelovalci, ki } \\
\text { sredstva uporabljajo) }\end{array}$ & $\begin{array}{c}\text { Ob pojavu } \\
\text { bolezni ali } \\
\text { škodljivca: } 69 \%\end{array}$ & \multicolumn{2}{|c|}{$\begin{array}{l}\text { Pozimi oziroma v } \\
\text { prvi polovici rastne } \\
\text { dobe: } 19 \%\end{array}$} & $\begin{array}{l}\text { V rednih časovnih } \\
\text { presledkih v rastni } \\
\text { dobi: } 5 \%\end{array}$ & $\begin{array}{l}\text { Redko, } \\
\text { ne vsako } \\
\text { leto: } 7 \%\end{array}$ \\
\hline $\begin{array}{l}\text { Uporaba sredstev danes in } \\
\text { pred } 10 \text { leti }\end{array}$ & $\begin{array}{c}\text { Danes } \\
\text { uporabljam } \\
\text { manj sredstev: } \\
46 \%\end{array}$ & \multicolumn{2}{|c|}{$\begin{array}{l}\text { Danes uporabljam } \\
\text { več sredstev: } 21 \%\end{array}$} & \multicolumn{2}{|c|}{$\begin{array}{c}\text { Poraba sredstev danes in pred } 10 \\
\text { leti je približno enaka: } 33 \%\end{array}$} \\
\hline
\end{tabular}

*Vprimeru, da obdelovalec uporablja določeno vrsto gnojila, smo pripisali vrednost 1. Enako so analizirani tudi drugi odgovori v izvedeni anketi med obdelovalci zasebnih vrtov.

** Odstotek je tako visok zaradi dolgoletnega obdelovanja vrtov (le $7 \%$ anketiranih obdelovalcev obdeluje vrt manj kot 20 let). Rezultatov analiz se obdelovalci večinoma ne spomnijo. Večina obdelovalcev vzorca $v$ analizo ni oddala namerno, temveč ker se je ponudila priložnost (npr. analize je izvedel kdo od sorodnikov in podobno). Realnejši odstotek je 1-2\%.

Z vrtovi je povezana množica obdelovalcev z zelo raznolikimi vrtnarskimi navadami; predvsem so nas zanimali podatki, ki se nanašajo na gnojenje in uporabo fitofarmacevtskih sredstev (preglednica 1). Obdelovalci vrtov uporabljajo raznolike kombinacije gnojil, najbolj zastopana so živinska gnojila in kompost, $41 \%$ obdelovalcev pa uporablja mineralna gnojila (slika 6). Številne analize prsti, ki so bile opravljene na vrtovih, kjer gojijo zelenjavo (tudi na vrtičkarskih kompleksih), so pokazale, da so vrtovi preveč gnojene površine. Ponekod tudi nekaj let ne bi bilo potrebno gnojiti ali pa bi bilo treba uporabljati takšna gnojila, ki pretežno vsebujejo le hranilo, ki ga v prsti primanjkuje (npr. kalijevo gnojilo). 
Po podatkih anketiranja uporablja fitofarmacevtska sredstva manj kot polovica obdelovalcev, v desetletju pa se je uporaba sredstev zmanjšala. Tako v uporabi kot na trgu je vedno več bioloških pripravkov. Največ obdelovalcev je sredstva uporabljalo v primeru pojava bolezni na rastlini, manj v prvi polovici rastne dobe ali v rednih časovnih presledkih. Dostop malih uporabnikov do fitofarmacevtskih sredstev je močno omejil zakon iz leta 2007, po katerem je pogoj za njihov nakup opravljen tečaj iz uporabe sredstev za varstvo rastlin. Okoli $5 \%$ obdelovalcev je že imelo (ali bo imelo v kratkem) opravljen tečaj - to skupino vrtnarjenje tudi nekoliko bolj poglobljeno zanima in se uporabi fitofarmacevtskih sredstev ne namerava odreči.

Analize vsebnosti fitofarmacevtskih sredstev v prsti in pridelkih na ljubljanskih vrtičkih so pokazale neobremenjenost tako prsti kot pridelkov. Ugotovitev v določeni meri velja tudi za zelenjavne vrtove, saj sta si pojava v marsičem podobna. Zelenjavo zaužijejo obdelovalci sami in zato je razumljivo, da pri uporabi fitofarmacevtskih sredstev zelo pazijo oziroma jih uporabljajo v zmernih (majhnih) količinah. Pri zmanjšani in bolj pazljivi uporabi sredstev odigrajo informacije iz medijev pomembno vlogo. Okoljska ozaveščenost obdelovalcev narašča, hkrati pa so obdelovalci sami poudarjali, da bi želeli izvedeti še več podrobnejših informacij - tako o problematiki okolja kot o pravilni uporabi gnojil in fitofarmacevtskih sredstev.

Pri raziskavi smo se vseskozi soočali z načinom vrednotenja dejavnosti na vrtovih z vidika varstva okolja. Dejavnost lahko vrednotimo na dveh ravneh $-\mathrm{z}$ vidika strokovnosti samega obdelovanja vrta (kolikor lahko slednje ocenimo) in $\mathrm{z}$ vidika potencialnih vplivov na okolje.

Pri strokovnosti glede pravilne uporabe gnojil in fitofarmacevtskih sredstev izpostavljamo:

- obdelovalci so pri uporabi fitofarmacevtskih sredstev bolj pazljivi kot pri uporabi gnojil; glede dojemanja nevarnosti za okolje postavljajo fitofarmacevtska sredstva na prvo mesto, sledijo mineralna gnojila;

- polovica anketiranih obdelovalcev ne loči pravilno, da imajo vrtnine zelo različne potrebe po rastlinskih hranilih (vprašanje o paradižniku in solati); veliko obdelovalcev gnoji vse enako;

- $\quad$ številne analize prsti so pokazale, da so vrtovi preveč gnojeni;

- obdelovalci se redko odločajo za analizo prsti - največkrat naročijo analizo v primeru suma, da je na njihovem vrtu nekaj narobe;

- fitofarmacevtska sredstva uporablja manj kot polovica obdelovalcev; pred desetletjem je skoraj polovica uporabnikov fitofarmacevtskih sredstev uporabljala več sredstev kot danes;

- na tržišču je vedno več bioloških sredstev za varstvo rastlin;

- okoljska ozaveščenost narašča, obdelovalci vrtov so priznavali, da o varovanju okolja (zlasti tal in podzemne vode) ne vedo dovolj in so hkrati izkazali odprtost za učenje;

- meritve aktivnih ostankov fitofarmacevtskih sredstev $\mathrm{v}$ prsti in rastlinah so pokazale zelo ugodno stanje.

Z vidika (potencialnih) vplivov na okolje ločimo vplive na prst, pridelke in podtalnico. $\mathrm{Na}$ vrtovih je največji problem preobilno gnojenje. Pri problemu izpiranja nitratov in ovre- 
dnotenju njihovega morebitnega vpliva na kakovost podzemne vode moramo upoštevati naslednja dejstva:

- zasebni zelenjavni vrtovi pokrivajo le $0,36 \%$ površine vodovarstvenega območja IIA in $0,95 \%$ površine vodovarstvenega območja IIB (podatki temeljijo na nekoliko starejših ortofotoposnetkih); opazen je trend krčenja vrtov;

- v primerjavi z obsegom drugih rab na vodovarstvenih območjih (predvsem kmetijske) je skupna površina vrtov zanemarljiva;

- hitrost izpiranja je odvisna od številnih lastnosti prsti. Dejstvo, da so zasebni vrtovi zelo rodovitne površine z veliko organske snovi, na splošno upočasnjuje izpiranje;

- vrtovi na ožjih vodovarstvenih območjih Ljubljanskega polja tvorijo razpršen vzorec, kar zmanjšuje možne negativne vplive na kakovost ljubljanske podtalnice;

- analize vode kažejo, da je problem obremenjenosti podtalnice z nitrati vedno manjši. Druge dejavnosti imajo bistveno večji prispevek k onesnaževanju vode $\mathrm{z}$ nitrati kot obdelovanje zasebnih vrtov.

Nestrokovno vrtnarjenje oziroma uporaba gnojil lahko ogroža zdravje človeka. Vsebnost nitratov v pridelkih je pomemben kazalec kakovosti pridelkov. Opravljene analize pridelkov z vrtičkarskih območij v Ljubljani so pokazale, da so solatnice obremenjene z nitrati.

Vrednotenje obdelovanja zasebnih zelenjavnih vrtov z okoljskega vidika nam pokaže natančnejšo sliko o obstoječih negativnih vplivih te dejavnosti na okolje. Na splošno lahko ugotovimo, da smo bili pred opravljeno raziskavo do omenjene dejavnosti veliko bolj kritični kot po njej. Pri vrednotenju dejavnosti na vrtovih in dobljenih rezultatih izpostavljamo tudi problem pomanjkanja podatkov ter problem raznolikosti vrtov in obdelovalnih navad številnih obdelovalcev $\mathrm{v}$ povezavi s prepoznavanjem/vrednotenjem vplivov na okoljske sestavine. S precejšnjo gotovostjo lahko trdimo, da je uporaba fitofarmacevtskih sredstev na vrtovih primerna. Tudi okoljska ozaveščenost pri obdelovalcih vrtov glede uporabe sredstev ( narašča. Drugače je pri gnojenju. Veliko vrtov je pregnojenih, obdelovalci pa se ne zavedajo, da gnojijo preveč. Pretirano gnojenje je vir izpiranja nitratov, na drugi strani pa lahko nitrati preko zaužite zelenjave ogrožajo človeško zdravje. Količina izpranih nitratov je omejena z majhno skupno površino vrtov, analize nitratov v solatnicah z vrtičkarskih območij Ljubljane pa pokažejo onesnaženost pridelkov, vendar le-ta še ni kritična.

Pomembno je, da v prihodnje seznanimo obdelovalce vrtov s problemom preobilnega gnojenja ter tako odpravimo največjo pomanjkljivost pri obdelovanju vrtov. Le tako bomo lahko na vrtnarjenje gledali kot na dobrodošlo dejavnost, ki zagotavlja zdravo hrano in ne povzroča škode okolju in vpletenim ljudem.

\section{Viri in literatura}

Anketiranje vrtičkarjev v Mestni občini Ljubljana. Rezultati za izbrana anketna vprašanja. Geografski inštitut Antona Melika ZRC SAZU. Ljubljana 2006.

Kalia 2008: Pogovor o prodaji gnojil in fitofarmacevtskih sredstev (osebni vir, april 2008).

Kladnik, D. 2003: Pomen in perspektive kmetijstva znotraj ljubljanskega avtocestnega obroča. Geografski vestnik 75, 2. Ljubljana. 
Kmetijski inštitut Slovenije 2006. Rezultati analize tal in gnojilni nasveti (osebni vir, marec 2008).

Lampič, B. 2007: Razvojna in okoljska vloga kmetijstva v Mestni občini Ljubljana. Dela 28, Ljubljana.

Leskošek, M. 1993: Gnojenje: za velik in kakovosten pridelek, za zboljšanje rodovitnosti tal in varovanje narave. Kmečki glas. Ljubljana.

Ljubljana. Mestni načrt $1: 20.000$. Geodetski zavod Slovenije. Ljubljana 1994.

Mestna občina Ljubljana. Digitalni barvni ortofotoposnetki za območje Ljubljanskega polja, Oddelek za ravnanje z nepremičninami (posnetki so za leti 2003 in 2005).

Polajnar, K. 2008: Vpliv vrtičkarske dejavnosti na zdravje ljudi. Seminarska naloga, Univerza v Ljubljani, Univerzitetni podiplomski študij varstva okolja. Ljubljana.

Rejec Brancelj, I., Smrekar A., Kladnik, D. 2005: Podtalnica Ljubljanskega polja. Geografija Slovenije 10. Založba ZRC. Ljubljana.

Simoneti, M. 1997: Usmeritve in pogoji za nadaljnji razvoj vrtičkarstva v Ljubljani. Razvojno aplikativna enoletna raziskava. Mestna občina Ljubljana.

Smrekar, A. 2006: Zavest ljudi o pitni vodi. Geografija Slovenije 12. Založba ZRC. Ljubljana

Strajnar S. 2008: Okoljevarstvena problematika zasebnih vrtov na vodovarstvenih območjih Ljubljane. Diplomsko delo, Oddelek za geografijo, Filozofska fakulteta. Ljubljana.

Sušin, J. 2003: Okoljske posledice uporabe gnojil v kmetijstvu. Medmrežje: http://www.zzvce.si/uploads/posledice\%20uporabe\%20gnojil\%20v\%20kmetijstvu.pdf (2.12.2007).

Sušin, J. 2008: Pogovor o problematiki gnojenja na vrtovih (osebni vir, januar 2008).

Sušin, J., Kmecl, V., Gregorčič A. 2006: A survey of nitrate and nitrite content of fruit and vegetables grown in Slovenia during 1996-2002. Food additives and contaminants 23, 4. London.

Uredba o vodovarstvenem območju za vodno telo vodonosnika Ljubljanskega polja. Uradni list RS 120/2004. Ljubljana.

Urbanc, J., Jamnik, B. 2007: Porazdelitev in izvor nitratov v podzemni vodi Ljubljanskega polja. Geologija 50, 2. Ljubljana.

Vrtičkarstvo v Mestni občini Ljubljana kot vir onesnaževal v tleh, pridelani hrani in podzemni vodi. 2. fazno poročilo. Kmetijski inštitut Slovenije. Ljubljana 2007.

Vrtko 2008: Pogovor o prodaji gnojil in fitofarmacevtskih sredstev (osebni vir, april 2008).

\section{ENVIRONMENTAL PROTECTION: PRIVATE VEGETABLE GARDENS ON WATER PROTECTED AREAS IN LJUBLJANA}

\section{Summary}

Private vegetable gardens in the urban and suburban area of Ljubljana represent a very small fraction of agricultural land but many people have strong ties with these areas. According to gardeners' answers, the main motives for gardening are production of healthy food and recreation.

The Anton Melik Geographical Institute has made a three-year long research project on allotment gardens and as welcome addition to knowledge about small gardens and ways 
of gardening in Ljubljana and surroundings (on declared water protected areas) a research among private gardeners was considered. The field study focused on existing pressures on environment and, partly, on environment consciousness of the gardeners. Results were also evaluated with numerous chemical analyses of nutrients in soil and concentrations of active substances of phytopharmaceutical products in soil and vegetables (taken from allotment gardens).

At first, the evidence of vegetable gardens on inner water protected areas was made (the minimum area for digitalization was 5 sq. m). Private vegetable gardens cover 27.6 hectares in the investigated area, i.e. this non-profitable gardening covers $0.36 \%$ of IIA and $0.95 \%$ of IIB water protected areas. Comparing this with other land uses, especially agriculture, this is a very small fraction of area, but, from environmental point of view, gardens are much more important because of large number of gardeners and very different ways of gardening which cannot be controlled at all (the present survey was the first one about gardeners' habits at all).

After twenty or more years of gardening just about one third of gardeners know that their gardens are located on water protected areas. The knowledge of water protected area is linked with degree of education and the vicinity of water pumping areas. In urban area (southern part of inner water protected areas: Šiška, Bežigrad, Nove Jarše) most gardeners are not aware of having gardens on water protected areas at all (Figure 4).

Gardeners usually combine different types of fertilizers: $41 \%$ of them use mineral fertilizers, while the most used types are stable manure and compost (Figure 6). Analyses of soil samples, taken from allotment gardens, show that most gardens are over-manured. Analyses of nitrates in vegetable (chicory and endive) showed that around $20 \%$ of samples have concentrations evaluated as inappropriate (more than $1000 \mathrm{mg} / \mathrm{kg}$ ). On the one hand, over-manured gardens represent a potential burdening factor for quality of groundwater and, on the other, risk for human health. It is important to underline the gardeners are not aware of over-manured gardens and in nearly half of cases their gardening can be marked as unprofessional (in nearly half of cases they did not know that tomato needs more nutrient than lettuce; Figure 5). If more gardeners would give soil samples from their gardens for chemical analysis, they would be better aware of their over-manured gardens.

The application of phytopharmaceutical products and its correct usage in private gardens differs from the use of fertilizers. Gardeners seem to be more careful and they consider phytopharmaceutical products far more dangerous for environment than fertilizers. A share of $43 \%$ asked gardeners use such products but, majority of them, only in cases when it is really necessary. Nearly half of users of phytopharmaceutical products claim that ten years ago their usage was higher than today. On the other hand, we can identify a group of users who already have licenses for buying phytopharmaceutical products or have serious intention of participating in courses for correct use of these products (nearly $5 \%$ of asked gardeners). Analyses of different active substances of phytopharmaceutical products in vegetables (chicory and endive), taken from allotment gardens, show environmentally good results. In all samples, the concentrations of active substances were under the detection limit of used method. These results are better than they were expected. With high degree of certainty, we can conclude that vegetables in private gardens, just like in allotment gardens in Ljubljana 
and surroundings, are irreproachable from the phytopharmaceutical point of view.

On results from field survey and numerous chemical analyses we can conclude that gardens are the most problematical because of over-fertilization. Their scattered pattern (in inner water protected areas) reduces washing out of nitrates and because of small area (and gardens are expected to shrink for 10-20\% in the next decade) nitrates are not expected to have significant influence on groundwater quality. Human health might be more under threat.

Gardening is very important activity for older people and if problems with overfertilization will be reduced and environmental consciousness will rise a little bit, we could be able to judge this activity as welcome and non-problematical from environmental point of view. Even gardeners themselves claim that they would like to know more about environmental issues and correct use of fertilizers. According to field results, media is the most appropriate way to do it. 